\title{
PENGEMBANGAN LEMBAR KERJA PESERTA DIDIK (LKPD) LUAR KELAS BERBASIS KONTEKSTUAL UNTUK MENINGKATKAN LITERASI SAINS XI MIPA SMAN 8 MAROS
}

\section{DEVELOPMENT OF STUDENT'S OUTDOOR WORKSHEET BASED ON CONTEX TO IMPROVE LITERACY OF SCIENCE ON GRADE XI SCIENCE SMAN 8 MAROS}

\author{
${ }^{1)}$ Triya Azmarita, ${ }^{2)}$ Helmi, ${ }^{3)}$ Aisyah Azis \\ Universitas Negeri Makassar \\ Kampus UNM Parangtambung Jln. Daeng Tata Raya, Makassar, 90224 \\ ${ }^{1)}$ e-mail : triyazmaritaa@gmail.com
}

\begin{abstract}
Abstrak. Pengembangan Lembar Kerja Peserta Didik (Lkpd) Luar Kelas Berbasis Kontekstual Untuk Meningkatkan Literasi Sains Xi Mipa Sman 8 Maros. Penelitian ini bertujuan untuk mengetahui validitas lembar kerja peserta didik (LKPD) luar kelas berbasis kontekstual untuk meningkatkan literasi sains peserta didik XI MIPA SMAN 8 Maros. LKPD luar kelas berbasis kontekstual untuk meningkatkan literasi sains yang dirancang berbasis kontekstual merujuk pada kearifan lokal di Maros dengan objek "Bakul Maulid" adalah perangkat pembelajaran dalam melakukan penugasan berupa penguatan konsep fisika diluar kelas yang menuntun peserta didik agar dapat mengaplikasikan materi fisika yang telah di ajarkan di kelas dalam kehidupan seharihari. Penelitian pengembangan Lembar Kerja Peserta Didik (LKPD) luar kelas BerbasisKontekstual dirancang dengan menggunakan model ADDIE (Analysis, Design, Development, Implementation, and Evaluation). Hasil validasi pakar diperoleh nilai koefisien $\mathrm{r}$ yaitu 1 berdasarkan analisis Gregory yang menunjukkan valid untuk digunakan. Hasil persepsi guru terhadap Lembar Kerja Peserta Didik (LKPD) luar kelas berbasis kontekstual untuk meningkatkan literasi sains diperoleh rata-rata persentase untuk setiap aspek adalah 66,6\% yang menunjukkan bahwa guru setuju artinya guru memberi respon positif terhadap LKPD. Hasil persepsi peserta didik terhadap Lembar Kerja Peserta Didik (LKPD) luar kelas berbasis kontekstual untuk meningkatkan literasi sains diperoleh rata-rata persentase untuk setiap aspek adalah $83,4 \%$ yang menunjukkan bahwa peserta didik sangat setuju terhadap pembelajaran dengan menggunakan LKPD. Hasil test awal sebelum diuji cobakan LKPD luar kelas berbasis kontekstual untuk meningkatkan literasi sainspeserta didik dalam dimensi sikap sangatlah rendah. Hasil test akhir setelah dilakukan uji coba LKPD luar kelas berbasis kearifan lokal untuk meningkatkan literasi sains menunjukkan terdapat peningkatan literasi sains dalam dimensi sikap terhadap peserta didik. Berdasarkan kedua hasil test tersebut dapat simpulkan bahwa terdapat peningkatan literasi sains dalam dimensi sikap terhadap peserta didik XI MIPA SMAN 8 Maros
\end{abstract}

Kata kunci : Kontekstual, Lembar Kerja Perserta Didik, Pembelajaran di Luar Kelas, Literasi Sains

\begin{abstract}
Development Of Student's Outdoor Worksheet Based On Contex To Improve Literacy Of Science On Grade Xi Science Sman 8 Maros. This study aims to determine the validity of contextual class-based student worksheets (LKPD) to improve scientific literacy of XI MIPA students at SMAN 8 Maros. Contextual-based LKPD outside the classroom to improve science literacy that is designed based on contextual refers to local wisdom in Maros with the object "Bakul Maulid" is a learning device in carrying out assignments in the form of strengthening physics concepts outside the classroom that guide students to be able to apply the physics material that has been taught in class in everyday life. Research on the development of Student Worksheet (LKPD) outside the Contextual Based class was designed using the ADDIE model (Analysis, Design, Development, Implementation, and Evaluation). The results of expert validation obtained by the coefficient $r$ is 1 based on Gregory's analysis which shows valid to use. The results of teacher perceptions of student-based worksheets (LKPD) outside the classroom based on context to improve scientific literacy obtained an average percentage for each aspect is $66.6 \%$ which indicates that the teacher agrees means that the teacher gives a positive response to the LKPD. The results of students' perceptions of Student Class Worksheets (LKPD) outside the context-based class to improve scientific literacy obtained an average percentage for each aspect was $83.4 \%$ which showed that students strongly agreed to learning by using LKPD. The preliminary test results before being tested try contextual class-based LKPD to improve student science literacy in a very low attitude dimension. The final test results after testing out of class LKPD based on local
\end{abstract}


wisdom to improve scientific literacy showed that there was an increase in scientific literacy in the dimensions of attitudes toward students. Based on the two results of the test it can be concluded that there is an increase in scientific literacy in the dimensions of attitudes towards XI MIPA students of SMAN 8 Maros.

Keywords : Contextual, Student Worksheet, Outside Class Learning, Science Literacy.

\section{PENDAHULUAN}

Pada era globalisasi seperti saat ini, Indonesia harus mampu memiliki pelajar dengan lulusan yang memiliki kemampuan abad 21 yaitu mampu berpikir kritis, dan kreatif di dalam bidang literasi, teknik, sains, seni dan matematika. Lebih lanjut dijelaskan keterampilan abad 21 ini muncul dari sebuah asumsi bahwa saat ini individu hidup dan tinggal dalam lingkungan yang sarat akan teknologi, dimana terdapat berlimpah informasi, percepatan kemajuan teknologi yang sangat tinggi dan pola komunikasi dan kolaborasi yang baru. Kesuksesan siswa dalam dunia pendidikan di era digital ini sangat tergantung pada keterampilan yang diharuskan untuk dimiliki, salah satunya adalah kemampuan literasi yang baik.

Fisika merupakan ilmu alam termasuk rumpun IPA yang memiliki karakteristik meliputi objek ilmiah, cara memperoleh serta kegunaannya. Konsep fisika yang relatif banyak harus diserap siswa dalam waktu yang terbatas membuat siswa sulit dalam mempelajari konsep fisika.

Kompetensi yang diinginkan kurikulum 2013 merupakan pembelajaran yang bermakna yang memungkinkan siswa menerapkan konsepkonsep fisika dan berpikir tingkat tinggi yang meliputi sikap, proses, produk dan aplikasi. Hal tersebut sejalan dengan komponen-komponen yang terdapat dalam literasi sains. PISA mendefinisikan literasi sains sebagai kemampuan untuk menggunakan pengetahuan ilmiah, mengidentifikasi pertanyaan, dan menyimpulkan sesuatu berdasarkan fakta untuk memahami dan membuat keputusan mengenai sifat dan perubahannya dari aktivitas manusia (Rosdiana, 2017). Empat dimensi literasi sains diungkapkan dalam PISA yaitu pengetahuan ilmiah, proses ilmiah, konteks aplikasi imiah dan sikap ilmiah.

Literasi sains adalah prasyarat untuk pembangunan bangsa, khususnya untuk kualitas sumber daya manusia yang melek ilmu pengetahuan dan teknologi. Ini menunjukkan bahwa pendidikan mengharapkan peserta didik untuk memiliki literasi sains yang nantinya dapat membawa Indonesia ke pengembangan lebih lanjut ( $P$, 2018). Literasi sains dirasa penting karena dapat mengembangkan beberapa kemampuan diri salah satunya adalah dapat membuat penjelasan mengenai fenomena yang terjadi berdasarkan konsep yang telah dipahami, serta dapat menggunakan metode ilmiah untuk memecahkan masalah dalam kehidupan seharihari. Literasi sains memiliki makna yakni dapat mengaplikasikan konsep-konsep keilmuwan untuk memecahkan masalah sehari-hari (Aisyah, 2017).

Berdasarkan hasil observasi awal di lapangan, selama ini guru hanya mengandalkan buku paket siswa dalam proses pembelajaran. Buku-buku di lapangan belum menunjukkan keseimbangan kategori literasi sains dan hanya menekankan pada pengetahuan sains. Terbatasnya bahan ajar yang aplikatif juga membuat peserta didik tidak mengetahui kebermaknaan mata pelajaran fisika dalam kehidupan sehari-hari sehingga membuat minat dan motivasi peserta didik relatif rendah. Bahan ajar yang digunakan adalah buku teks dari beberapa penerbit dan memiliki beberapa kekurangan yaitu sajian pada buku masih bersifat 
umum dan belum disesuaikan dengan lingkungan belajar peserta didik.

Oleh sebab itu diperlukan media pendidikan dalam proses pembelajaran untuk membantu meningkatkan kualitas proses pembelajaran (Munirah, 2014). Bahan ajar sebagai media pendidikan dalam usaha menguasai materi pembelajaran harus memenuhi kebutuhannya, serta kompetensi yang disesuaikan dengan karakteristik sasaran, sehingga bahan ajar dapat menyelesaikan kesulitan dalam belajar (Depdiknas, 2008). Sehingga peneliti tertarik untuk mengembangkan bahan ajar dalam bentuk Lembar Kerja Peserta Didik (LKPD) luar kelas berbasis kontekstual sebagai penunjang proses pembelajaran. Inti dari CTL (contextual Teaching and Learning) adalah keterkaitan dari setiap konten atau subjek pembelajaran dengan kehidupan nyata. Untuk menghubungkan CTL dapat dilakukan dengan berbagai cara, karena berkaitan dengan kondisi faktual atau pengalaman kehidupan nyata (Rusman, 2014). Selain itu lembar kegiatan merupakan salah satu alternatif pembelajaran yang tepat bagi peserta didik untuk menambah informasi tentang konsep yang dipelajari melalui kegiatan belajar secara sistematis (Andi, 2015). Dengan demikian, Pengajaran dan Pembelajaran mengunakan LKPD Kontekstual akan lebih menarik karena peserta didik merasakan manfaat dari pelajaran yang mereka dapatkan di dalam kelas,

LKPD luar kelas berbasis kontekstual adalah salah satu bahan ajar yang berupa lembaran-lembaran yang berisi tugas-tugas yang harus dikerjakan peserta didik dimana isi pada LKPD tersebut dikaitkan dengan konteks kehidupan nyata mereka sehingga siswa dapat mengetahui makna fisika dalam kehidupan sehari-hari.

Adapun tujuan penelitian ini adalah untuk mengetahui: Penelitian ini bertujuan untuk mengetahui: 1) Validitas lembar kerja peserta didik (LKPD) luar kelas berbasis kontekstual XI
MIPA SMAN 8 Maros. 2) Persepi guru terhadap lembar kerja peserta didik (LKPD) luar kelas berbasis kontekstual XI MIPA SMAN 8 Maros. 3) Persepsi perserta didik terhadap lembar kerja peserta didik (LKPD) luar kelas berbasis kontekstual XI MIPA SMAN 8 Maros.

\section{METODE}

Jenis penelitian ini adalah jenis penelitian dan pengembangan dengan model penelitian ADDIE yaitu Analysis, Design, Development, Implementation, dan Evaluation (Henry, 2000). Penelitian ini dilaksanakan pada bulan september sampai dengan bulan november 2018 bertempat di SMAN 8 Maros. Yang menjadi subjek adalah 4 peserta didik yang tidak menyukai pelajaran fisika. Instrumen yang digunakan dalam penelitian ini adalah 1) Instrumen penilaian kevalidan produk, 2) Angket persepsi guru terhadap LKPD, 3) Angket persepsi peserta didik terhadap LKPD.

Teknik pengumpulan data yang digunakan adalah teknik teknik wawancara yang berkaitan langsung dengan observasi awal, teknik documentasi, teknik data validasi ahli, teknik data persepsi guru terhadap LKPD, dan teknik data persepsi peserta didik terhadap LKPD. Adapun teknik analisis data yang dilakukan oleh peneliti adalah dengan melakukan 1) Data kevalidan diperoleh dengan cara menganalisis hasil penilaian 2 orang ahli LKPD yang dikembangkan dengan menggunakan analisis Gregory. 2) Data persepsi guru terhadap LKPD ditinjau dari presetasi respon guru terhadap LKPD dan selanjutnya menentukan kategori untuk setiap aspek yang dinilai. 3) Data persepsi peserta didik terhadap LKPD ditinjau dari presetasi respon peserta didik terhadap LKPD dan selanjutnya menentukan kategori untuk setiap aspek yang dinilai.

\section{HASIL DAN PEMBAHASAN}




\section{Ketercapaian Tujuan Penelitian}

Pada bagian ini, dikemukakan paparan hasil penilaian validator dan uji coba perangkat pembelajaran sebagai berikut.

\section{Lembar Kerja Peserta Didik (LKPD) luar kelas}

Berdasarkan analisis penilaian oleh kedua validator, diperoleh bahwa pada bahan ajar yaitu Lembar Kerja Peserta Didik (LKPD) luar kelas berbasis kontekstual untuk meningkatkan literasi sains diperoleh hasil 95,9 \% yaitu berada pada kategori sangat kuat. Hal ini menunjukkan bahwa LKPD layak digunakan sebagai bahan ajar.

Berdasarkan analisis penilaian oleh dua validator, diperoleh bahwa LKPD luar kelas berbasis kontekstual untuk meningkatkan literasi sains diperoleh hasil valid dengan nilai koefisien validasi (r) adalah 1 yang menyatakan valid untuk semua aspek.

Penilaian guru mata pelajaran fisika terhadap LKPD luar kelas berbasis kontekstual untuk meningkatkan literasi sains diperoleh dari angket presepsi guru terhadap LKPD luar kelas berbasis kontekstual untuk meningkatkan literasi sains. LKPD dinilai oleh tiga orang guru mata pelajaran fisika. Dari hasil persepsi ketiga guru mata pelajaran fisika diperoleh bahwa LKPD layak digunakan sebagai bahan ajar dengan presentase kelayakan $66,6 \%$ berada pada kategori kuat. Dari hasil wawancara terhadap guru pelajaran fisika LKPD luar kelas berbasis kontekstual layak digunakan karena dapat membuat peserta didik lebih mudah paham terhadap konsep fisika sehingga mereka dapat menerapkan konsep-konsep tersebut pada kehidupan sehari-hari. Selain itu LKPD luar kelas berbasis kontekstual juga dapat meningkatkan literasi sains peserta didik.

Sementara untuk penilain peserta didik terhadap LKPD luar kelas berbasis kontekstual diperoleh dari angket persepsi peserta didik terhadap LKPD setelah dilakukan uji coba. Secara keseluruhan peserta didik menyukai penggunaan LKPD luar kelas berbasis kontekstual dalam proses pembelajaran fisika. Hal tersebut dibuktikan saat proses uji coba peserta didik sangat antusias dalam pembelajaran fisika. Peserta didik yang awalnya sulit untuk memahami konsep-konsep fisika dengan LKPD luar kelas berbasis kontekstual dan dibantu dengan objek nyata bakul maulid ini peserta didik dengan mudah memahami konsep-konsep fisika yang terdapat pada bakul maulid. Setelah melakukan uji coba terbatas diperoleh besar presentase rata-rata respon peserta didik terhadap LKPD luar kelas berbasis kontekstual adalah $83,4 \%$ dengan kategori sangat kuat. Hal tersebut menunjukkan bahwa secara keseluruhan peserta didik sangat setuju dengan penggunaan LKPD luar kelas berbasis kontekstual untuk meningkatkan literasi sains.

Setelah melakukan uji coba produk temuan peneliti yang ditemukan dalam proses penelitian yaitu LKPD luar kelas berbasis kontekstual berperan dalam meningkatkan literasi sains peserta didik dalam hal sikap. Peserta didik awalnya tidak menyukai fisika dan memiliki persepsi fisika rumit, fisika sulit dipahami, dan tidak paham kebermaknaan fisika dalam kehidupan sehari-hari yang memicu peserta didik menjadi malas untuk belajar fisika, acuh tak acuh ketika guru menjelaskan berubah menjadi suka terhadap pelajaran fisika.

Adapun hasil peningkatan literasi sains dalam hal sikap sebagai berikut:

\section{a. Subjek I}

Awalnya subjek I sangat tidak suka fisika tetapi setelah diberikan LKPD berbasis kontekstual peserta didik ini menjadi suka dengan fisika karena lebih mudah memahami konsep-konsep fisika jika proses pembelajarannya secara praktek atau bersifat 
nyata sehingga dapat disimpulkan terdapat kebermaknaan material terhadap subjek I. Selain makna material subjek I juga memiliki makna potensial, hal itu ditandai dengan subjek I mampu menerapkan konsep-konsep fisika dalam kehidupan sehari-hari, namun untuk menunjukkan makna potensial subjek I masih memerlukan bimbingan dari pendidik. Meskipun masih membutuhkan bimbingan dari pendidik subjek I tetap dikatakan memiliki makna potensial seperti yang dijelaskan dalam teori Zone of Proximal Development (ZPD), dimana tingkat perkembangan potensial tampak dari kemampuan anak menyelasaikan tugas atau memecahkan masalah dengan bantuan orang dewasa.

\section{b. Subjek II}

Awalnya subjek II sangat tidak suka fisika tetapi setelah diberikan LKPD berbasis kontekstual peserta didik ini menjadi suka dengan fisika karena dengan penjelasan materi menggunakan objek bakul maulid menjadi lebih mudah memahami konsep fisika, sehingga dapat disimpulkan terdapat kebermaknaan material terhadap subjek II. Selain makna material subjek II juga memiliki makna potensial, hal itu ditandai dengan subjek II mampu menerapkan konsepkonsep fisika dalam kehidupan sehari-hari, namun untuk menunjukkan makna potensial subjek II masih memerlukan bimbingan dari pendidik. Meskipun masih membutuhkan bimbingan dari pendidik subjek II tetap dikatakan memiliki makna potensial seperti yang dijelaskan dalam teori Zone of Proximal Development (ZPD), dimana tingkat perkembangan potensial tampak dari kemampuan anak menyelasaikan tugas atau memecahkan masalah dengan bantuan orang dewasa.

\section{c. Subjek III}

Awalnya subjek III tidak terlalu suka dengan fisika tetapi setelah diberikan LKPD berbasis kontekstual peserta didik ini menjadi makin suka dengan fisika karena dengan penjelasan materi berbantuan objek bakul maulid membuat mudah memahami konsep fisika dan mengerti akan kebermaknaan fisika dalam kehidupan sehari-hari, sehingga dapat disimpulkan terdapat kebermaknaan material terhadap subjek III. Selain makna material subjek III juga memiliki makna potensial, hal itu ditandai dengan jawaban subjek III yang terdapat pada LKPD dimana subjek III mampu menerapkan konsep-konsep fisika dalam kehidupan sehari-hari. Tidak seperti halnya subjek I dan II, subjek III mampu menjelaskan penerapan konsep fisika dalam kehidupan seharihari secara rinci tanpa bimbingan dari pendidik.

\section{d. Subjek IV}

Awalnya subjek IV saya tidak terlalu suka dengan fisika tetapi setelah diberikan LKPD berbasis kontekstual peserta didik ini menjadi makin suka dengan fisika karena pembelajarannya tidak membosankan dan membuat peserta didik bisa terjun langsung dalam penemuan konsep-konsep fisika melalui objek bakul maulid, sehingga dapat disimpulkan terdapat kebermaknaan material terhadap subjek IV. Selain makna material subjek IV juga memiliki makna potensial, hal itu ditandai dengan jawaban subjek IV yang terdapat pada LKPD dimana subjek IV mampu menerapkan konsep-konsep fisika dalam kehidupan seharihari. Seperti halnya subjek III, subjek IV juga mampu menjelaskan penerapan konsep fisika dalam kehidupan sehari-hari secara rinci tanpa bimbingan dari pendidik.

\section{SIMPULAN}

Berdasarkan penelitian yang dilakukan, maka dapat disimpulkan: 
1. Pengembangan LKPD luar kelas berbasis kontekstual untuk meningkatkan literasi sains dinyatakan valid setelah memalui tim validator ahli.

2. Berdasarkan persepsi ketiga guru terhadap lembar kerja peserta didik (LKPD) luar kelas berbasis kontekstual untuk meningkatkan

4. literasi sains XI MIPA SMAN 8 Maros diperoleh hasil rata-rata untuk semua aspek

\section{DAFTAR RUJUKAN}

Aisyah. 2017. PengembanganLembar Kerja Siswa (LKS) Berorientasi Literasi Sains Pada Materi Larutan Elektrolit Dan Nonelektrolit. UNESA Journal of Chemical Education

Depdiknas. 2008. Panduan Pengembangan Bahan Ajar. Jakarta: Direktorat Jendral Manajemen Pendidikan Dasar dan Menengah.

Henry, Elington \& Baharuddin, Aris. 2000. A Practical Guide to InstructionalDesign International Review of Research in Open and Distance Learning 12(2).

P, Miftakhul Ilmi S. 2018. The Development of Science CPS (Colaborative Problem Solving) Learning Model to Improve Future Islamic Elementary School Teachers' Collaborative Problem- literasi sains XI MIPA SMAN 8 Maros diperoleh hasil rata-rata untuk semua aspek $66,6 \%$ yang menunjukkan bahwa aspek tersebut berada pada kategori kuat.

3. Berdasarkan persepsi peserta didik terhadap lembar kerja peserta didik (LKPD) luar kelas berbasis kontekstual untuk meningkatkan $83,4 \%$ yang menunjukkan bahwa aspek tersebut berada pada kategori sangat kuat

Solving Skills and Science Literacy. Unnes Science Education Journal.

Munirah. 2014. Upaya Peningkatan Mutu Hasil Belajar Melalui Media Pembelajaran. AULADUNA. Vol. 1, No. 1.

Andi, Prastowo. 2015. Kreatif Bebas Menciptakan Bahan Ajar: Menciptakan Metode Pembelajaran Yang Menarik dan Mengasyikkan. Yogyakarta: Diva Press.

Rosdiana. 2017. The Development of Discovery Learning Model to Improve Students' Science Literacy for Xi Grade Students Of Smk-Spp Negeri Samarinda. Unnes Science Education Journal.

Rusman. 2014. Model Pembelajaran: Mengembangkan Profesionalisme. Jakarta: King Grafindo Pranada. 